\title{
Vitamin C Intervention for Critical COVID-19: A Pragmatic Review of the Current Level of Evidence
}

\author{
Patrick Holford $^{1, *}$, Anitra C. Carr ${ }^{2}$ (D) Masuma Zawari ${ }^{2}$ and Marcela P. Vizcaychipi ${ }^{3,4}$ \\ 1 Founder of Institute for Optimum Nutrition, Ambassador House, Richmond TW9 1SQ, UK \\ 2 Nutrition in Medicine Research Group, Department of Pathology \& Biomedical Science, University of Otago, \\ Christchurch 8140, New Zealand; anitra.carr@otago.ac.nz (A.C.C.); masuma.zawari@otago.ac.nz (M.Z.) \\ 3 Faculty of Medicine, Imperial College, London SW7 2AZ, UK; m.vizcaychipi@imperial.ac.uk \\ 4 Intensive Care Medicine, Chelsea \& Westminster Hospital, London SW10 9NH, UK \\ * Correspondence: pat@patrickholford.com; Tel.: +44-(0)-7944-689108
}

Citation: Holford, P.; Carr, A.C.; Zawari, M.; Vizcaychipi, M.P. Vitamin C Intervention for Critical COVID-19: A Pragmatic Review of the Current Level of Evidence. Life 2021, 11, 1166. https://doi.org/10.3390/life11111166

Academic Editors: Jeanne A Drisko and Qi Chen

Received: 31 August 2021

Accepted: 27 September 2021

Published: 1 November 2021

Publisher's Note: MDPI stays neutral with regard to jurisdictional claims in published maps and institutional affiliations.

Copyright: (c) 2021 by the authors. Licensee MDPI, Basel, Switzerland. This article is an open access article distributed under the terms and conditions of the Creative Commons Attribution (CC BY) license (https:// creativecommons.org/licenses/by/ $4.0 /)$.

\begin{abstract}
Severe respiratory infections are characterized by elevated inflammation and generation of reactive oxygen species (ROS) which may lead to a decrease in antioxidants such as vitamin $\mathrm{C}$ and a higher requirement for the vitamin. Administration of intravenous vitamin $C$ to patients with pneumonia and sepsis appears to decrease the severity of the disease and potentially improve survival rate. Severe acute respiratory syndrome coronavirus 2 (SARS-CoV-2) infection causes pneumonia, sepsis and acute respiratory distress syndrome (ARDS) in severe cases, and is referred to as coronavirus disease 2019 (COVID-19). Patients with COVID-19 infection also appear to have depleted vitamin C status and require additional supplementation of vitamin $C$ during the acute phase of the disease. To date there have been 12 vitamin C and COVID-19 trials published, including five randomised controlled trials (RCTs) and seven retrospective cohort studies. The current level of evidence from the RCTs suggests that intravenous vitamin $C$ intervention may improve oxygenation parameters, reduce inflammatory markers, decrease days in hospital and reduce mortality, particularly in the more severely ill patients. High doses of oral vitamin $C$ supplementation may also improve the rate of recovery in less severe cases. No adverse events have been reported in published vitamin C clinical trials in COVID-19 patients. Upcoming findings from larger RCTs will provide additional evidence on vitamin supplementation in COVID-19 patients.
\end{abstract}

Keywords: vitamin C; SARS-CoV2; COVID-19; clinical trials; randomised controlled trials; intravenous vitamin $C$; pneumonia; sepsis; acute respiratory distress syndrome

\section{Introduction}

Coronaviruses are single-stranded ribonucleic acid viruses comprising a lipid bilayer containing crown-like spikes (Latin, Corona $=$ Crown) on their outer surface [1]. Infection with these viruses can affect both the upper and lower respiratory tract and can cause diseases ranging from a mild form, or common cold, to pneumonia [2]. In early December 2019, there were reports of infections with pneumonia-like symptoms of unidentified causes in China [3]. The infections were subsequently identified as being caused by a novel severe acute respiratory syndrome coronavirus 2 (SARS-CoV-2), the resultant disease being named coronavirus disease (COVID-19) in February 2020 [4]. Globally, as of August 2021, there have been over 200 million confirmed cases of COVID-19, including nearly 4.5 million deaths, reported [5]. Initial data indicated that the majority of patients were aged over 40 years, and that the risk of death increased with age [1]. Since then, numerous other risk factors have been identified, including specific underlying health conditions [6]. Currently, there is a global research effort to try and identify therapies that may help in the treatment of COVID-19.

Vitamin $C$ is an essential nutrient that has important roles in immune function, including antioxidant, anti-inflammatory, antithrombotic, and immuno-modulatory func- 
tions [7,8]. Vitamin C deficiency, defined as a plasma concentrations of $\leq 11 \mu \mathrm{mol} / \mathrm{L}$, is more common in the elderly, male gender, people with comorbidities, and low socioeconomic status [9]. These are also risk factors for COVID-19 infection [6]. Severe respiratory infections, such as pneumonia, are common clinical conditions that lead to a high requirement for vitamin $C$, thus providing grounds for active vitamin $C$ replacement in patients who suffer from severe respiratory infections [10]. Although a vitamin C intake of $200 \mathrm{mg}$ daily in healthy volunteers produces a saturating plasma concentration of 70 to $90 \mu \mathrm{mol} / \mathrm{L}$ [11,12], at least ten-fold higher doses (i.e., $2-3 \mathrm{~g} /$ day) are required to saturate the plasma of critically ill patients [13-15]. Critically ill patients are defined as patients at high risk for actual or potential life-threatening injuries and illnesses, requiring at least organ support and are continuously monitored in the intensive care unit (ICU). Vitamin C is generally administered parenterally to critically ill patients as it provides significantly higher circulating concentrations than enteral vitamin C [16].

Vitamin C administration in patients with pneumonia, sepsis and acute respiratory distress syndrome (ARDS) has shown potential benefits such as reducing duration of hospital and ICU stay and mortality [8]. Pneumonia, sepsis and ARDS are common complications of patients with severe COVID-19 and in March 2020, the World Health Organization highlighted vitamin $C$ as a potential adjunctive therapy with biologic plausibility for patients with critical COVID-19 [17]. This pragmatic review summarizes the current level of evidence available from published studies (randomised controlled trials [RCTs] and retrospective cohort studies) that have investigated enteral and parenteral vitamin C supplementation in patients with SARS-CoV2 infection and severe COVID-19.

\section{Vitamin C Status in Patients with COVID-19}

Significant evidence indicates that patients with severe respiratory infections have depleted vitamin $C$ status, with the prevalence of deficiency increasing with the severity of the condition [18-20]. The vitamin C status of patients with COVID-19 has been reported in several small observational studies (Table 1) [21-26]. Plasma concentrations of vitamin C in most of these patients were reported to be very low with $70-80 \%$ of the patients having hypovitaminosis $\mathrm{C}$ (plasma concentration $<23 \mu \mathrm{mol} / \mathrm{L}$ ) [22,24]. The low concentrations were despite patients receiving on average $124 \mathrm{mg} /$ day vitamin $C$ in their enteral or parenteral nutrition [26]. Interestingly, markers of oxidative stress were elevated in the COVID-19 patients relative to controls and there was an inverse correlation between oxidative stress markers and vitamin $C$ status in the patients [25]. Thus, vitamin $C$ supplementation appears warranted in these patients to address their hypovitaminosis $C$ and restore adequate plasma vitamin $C$ status [21]. It should be noted that short-term (i.e., 2-4 day) intervention with intravenous vitamin $C$ may not be of sufficient duration to provide lasting benefit as $15-25 \%$ of patients can return to hypovitaminosis $C$ status following cessation of intervention [15,27].

Table 1. Vitamin C status in patients with COVID-19.

\begin{tabular}{|c|c|c|c|}
\hline $\begin{array}{l}\text { Population } \\
\text { Location }\end{array}$ & Method & Findings & Reference \\
\hline $\begin{array}{l}18 \text { patients with ARDS }{ }^{1} \\
\text { Barcelona, Spain. }\end{array}$ & $\begin{array}{c}\text { Plasma }^{2} \\
\text { HPLC-PDA }^{2}\end{array}$ & $\begin{array}{l}17 \text { patients had }<8 \mu \mathrm{M} \text { vitamin } C \\
1 \text { patient had } 14 \mu \mathrm{M} \text { vitamin } C\end{array}$ & [23] \\
\hline $\begin{array}{l}21 \mathrm{ICU}^{3} \text { patients } \\
\text { Thornton, Colorado, USA }\end{array}$ & Serum & $\begin{array}{c}\text { Total cohort }(\mathrm{n}=21) \text { had } 22 \mu \mathrm{M} \text { vitamin } \mathrm{C} \\
(45 \% \text { were deficient, } 70 \% \text { were hypovitaminosis } C) \\
\text { Survivors }(\mathrm{n}=11) \text { had } 29 \mu \mathrm{M} \text { vitamin } C \\
\text { Non-Survivors }(\mathrm{n}=10) \text { had } 15 \mu \mathrm{M} \text { vitamin } C\end{array}$ & [22] \\
\hline $\begin{array}{l}31 \text { hospitalised patients } \\
51 \text { healthy } \\
\text { controlsShanghai, China }\end{array}$ & $\begin{array}{c}\text { Plasma } \\
\text { UHPLC-MS } 4\end{array}$ & $\begin{array}{c}6 \text { patients (no IVC }{ }^{5} \text { ) had } 11 \mu \mathrm{M} \text { vitamin } \mathrm{C} \\
25 \text { patients given } 100 \mathrm{mg} / \mathrm{kg} / \text { day IVC had } 76 \mu \mathrm{M} \\
51 \text { healthy controls had } 52 \mu \mathrm{M} \text { vitamin } \mathrm{C}\end{array}$ & [21] \\
\hline
\end{tabular}


Table 1. Cont.

\begin{tabular}{|c|c|c|c|}
\hline $\begin{array}{l}\text { Population } \\
\text { Location }\end{array}$ & Method & Findings & Reference \\
\hline $\begin{array}{c}50 \text { symptomatic patients } \\
21 \text { healthy controls } \\
\text { Jigwa, Nigeria }\end{array}$ & $\begin{array}{c}\text { Serum } \\
\text { Colourimetric }\end{array}$ & $\begin{array}{l}\text { Patients had } 19 \mu \mathrm{M} \text { vitamin } C \\
\text { Controls had } 25 \mu \mathrm{M} \text { vitamin } C\end{array}$ & [25] \\
\hline $\begin{array}{l}9 \mathrm{ICU} \text { patients with severe } \\
\text { pneumonia } \\
\text { Liège, Belgium }\end{array}$ & & $\begin{array}{l}\text { Patients had } 22 \mu \mathrm{M} \text { vitamin } \mathrm{C} \\
\text { (reference range: } 35-86 \mu \mathrm{M} \text { ) }\end{array}$ & [26] \\
\hline $\begin{array}{l}67 \text { patients with ARDS } \\
\text { Barcelona, Spain }\end{array}$ & $\begin{array}{l}\text { Plasma } \\
\text { HPLC }\end{array}$ & $\begin{array}{l}\text { Mean vitamin } C \text { concentration was } 8 \pm 3 \mu \mathrm{M} \\
55 \text { patients }(82 \%) \text { had values }<23 \mu \mathrm{M} \\
12 \text { patients }(18 \%) \text { had values }<6 \mu \mathrm{M}\end{array}$ & [24] \\
\hline \multicolumn{4}{|c|}{$\begin{array}{l}{ }^{1} \text { ARDS: acute respiratory distress syndrome, }{ }^{2} \text { PDA: photo diode array, }{ }^{3} \text { ICU: intensive care unit, }{ }^{4} \text { UHPLC-MS: ultra-high-performance } \\
\text { liquid chromatography-mass spectrometry, }{ }^{5} \text { IVC: intravenous vitamin C. Note: vitamin C concentrations }<11 \mu \mathrm{M} \text { are considered deficient, } \\
\text { and }<23 \mu \mathrm{M} \text { are considered hypovitaminosis C. }\end{array}$} \\
\hline \multicolumn{4}{|c|}{ 3. Randomised Controlled Trials with Intravenous Vitamin C } \\
\hline & \multicolumn{3}{|c|}{$\begin{array}{l}\text { The first published randomised placebo-controlled trial was carried out in Wuhan, } \\
\text { China, and administered IVC at a dose of } 12 \mathrm{~g} / 12 \mathrm{~h} \text { at a late stage ( } 10-17 \text { days after the } \\
\text { onset of the first symptoms) for seven days (Table } 2 \text { ) [28]. This trial reported a } 70 \% \text { reduced } \\
\text { ICU and hospital mortality in patients with sequential organ failure assessment (SOFA) } \\
\text { scores } \geq 3 \text { who received IVC relative to those who received placebo ( } 4 \text { vs. } 10 \text { days, } p=0.03 \text { ). } \\
\text { There was no difference in invasive ventilation-free days of the intervention vs. placebo } \\
\text { group overall ( } 26.5 \text { vs. } 10.5 \text { days, } p=0.56) \text {, however, this trial was halted early due to } \\
\text { diminishing patient numbers. Nevertheless, increased peripheral capillary oxygen satura- } \\
\text { tion/pulmonary function was observed in the IVC group relative to placebo }\left(\mathrm{PaO}_{2} / \mathrm{FiO}_{2} \text {; }\right. \\
229 \text { vs. } 151 \mathrm{mmHg}, p=0.01) \text {. Furthermore, the study group also had a lower inflammation } \\
\text { marker (interleukin- } 6 \text {, IL- } 6 \text { ) than the placebo group ( } 19 \text { vs. } 158 \mathrm{pg} / \mathrm{mL}, p=0.04) \text {. Patients } \\
\text { with worse organ dysfunction may have more severe vitamin C deficiency [29], which } \\
\text { could contribute to the benefit of intervention being more significant in the more severe } \\
\text { COVID-19 patients with higher baseline SOFA scores in this study. }\end{array}$} \\
\hline
\end{tabular}

Table 2. Randomised controlled trials investigating the effect of intravenous vitamin C (IVC) in patients with COVID-19.

\begin{tabular}{cc}
$\begin{array}{c}\text { Population } \\
\text { Mean Age } \\
\text { Location }\end{array}$ & $\begin{array}{c}\text { Intervention } \\
\text { Duration }\end{array}$ \\
\hline
\end{tabular}

54 patients with COVID-19-pneumonia and multiple organ injury

Age $=67 \pm 13$ years

Wuhan, Hubei, China

$$
\begin{gathered}
\operatorname{IVC}^{1} 24 \mathrm{~g} / \text { day }(\mathrm{n}=27) \\
\text { or placebo }(\mathrm{n}=29) \\
\text { for } 7 \text { days }
\end{gathered}
$$

\section{Findings (IVC vs. Control)}

\section{Reference}

Higher $\mathrm{PaO}_{2} / \mathrm{FiO}_{2}{ }^{2}$ (229 vs.

$151 \mathrm{mmHg}, p=0.01$ )

Lower Interleukin-6 (19 vs.

$158 \mathrm{pg} / \mathrm{mL}, p=0.04$ )

Lower ICU ${ }^{3}$ and hospital mortality in

patients with SOFA ${ }^{4}$ scores $\geq 3$ (4 vs.

10 days, $p=0.03$ )

No difference in ventilation-free days

(26.5 vs. 10.5 days, $p=0.56$ ) 
Table 2. Cont.

\begin{tabular}{|c|c|c|c|}
\hline $\begin{array}{l}\text { Population } \\
\text { Mean Age } \\
\text { Location }\end{array}$ & $\begin{array}{l}\text { Intervention } \\
\text { Duration }\end{array}$ & Findings (IVC vs. Control) & Reference \\
\hline $\begin{array}{c}150 \text { patients with severe } \\
\text { COVID-19 } \\
\text { Age }=52-53 \text { years } \\
\text { Karachi, Pakistan }\end{array}$ & $\begin{array}{l}\text { IVC } 50 \mathrm{mg} / \mathrm{kg} / \text { day } \\
\text { + standard therapy } \\
\text { or standard therapy } \\
\text { ( } 75 \text { per group) }\end{array}$ & $\begin{array}{c}\text { Patients became symptom-free earlier } \\
(7.1 \pm 1.8 \text { vs. } 9.6 \pm 2.1 \text { days, } p<0.0001) \\
\text { Patients spent fewer days } \\
\text { in the hospital } \\
(8.1 \pm 1.8 \text { vs. } 10.7 \pm 2.2 \text { days, } \\
p<0.0001) \\
\text { No difference in need for mechanical } \\
\text { ventilation }(16 \% \text { vs. } 20 \%, p=0.4) \\
\text { No difference in mortality }(9.3 \% \text { vs. } \\
14.6 \%, p=0.3)\end{array}$ & [30] \\
\hline $\begin{array}{c}60 \text { patients with COVID-19 } \\
\text { Age }=57-61 \text { years } \\
\text { Tehran, Iran }\end{array}$ & $\begin{array}{l}\text { IVC } 6 \mathrm{~g} / \text { day } \\
\text { + standard therapy } \\
\text { or standard therapy } \\
\text { ( } 30 \text { per group) } \\
\text { for } 5 \text { days }\end{array}$ & $\begin{array}{l}\text { Lower body temperature on 3rd day } \\
\text { of hospitalisation }(p=0.001) \\
\text { Improvement in oxygen saturation } \\
\text { on 3rd day } \\
\text { of hospitalisation }(p=0.014) \\
\text { No differences in length of ICU stay } \\
\text { or mortality }\end{array}$ & [31] \\
\hline
\end{tabular}

\footnotetext{
${ }^{1} \mathrm{IVC}$ : intravenous vitamin $\mathrm{C},{ }^{2} \mathrm{PaO}_{2} / \mathrm{FiO}_{2}$ : ratio of partial pressure of oxygen to fraction of inspired oxygen, ${ }^{3}$ ICU: intensive care unit, ${ }^{4}$ SOFA: sequential organ failure assessment.
}

An open label RCT of 150 critical COVID-19 patients in Karachi, Pakistan, administered IVC at $50 \mathrm{mg} / \mathrm{kg} /$ day ( $3.5 \mathrm{~g}$ for $70 \mathrm{~kg}$ person) along with standard care or standard therapy alone and reported that the IVC group became symptom-free earlier (7.1 vs. 9.6 days, $p<0.0001$ ), and spent fewer days in the hospital (8.1 vs. 10.7 days, $p<0.0001$; Table 2) [30]. However, there were non-significant reductions in need for mechanical ventilation and mortality. A similar open label RCT in Tehran, Iran, randomised 60 patients with COVID19 to $6 \mathrm{~g}$ /day IVC for five days or standard care [31]. Body temperature was reduced $(p=0.001)$ and oxygenation $\left(\mathrm{SpO}_{2}\right)$ increased $(p=0.014)$ after three days of receiving the treatment. There were, however, no differences in ICU length of stay or mortality.

\section{Retrospective Cohort Studies with Intravenous Vitamin C}

A retrospective cohort study in Xi'an, Shaanxi, China included 76 patients with COVID-19 who received a loading dose of IVC $6 \mathrm{~g} / 12 \mathrm{~h}$ on the first day, and $6 \mathrm{~g}$ once a day for the following four days compared to a cohort who received standard therapy alone (Table 3) [32]. A total of 48 (63\%) patients had a diagnosis of moderate COVID-19, and 28 $(37 \%)$ severe or critical disease. The median duration of symptoms before therapy was 12 days ( 8 to 16 days). Oxygen support status was improved compared with standard therapy (64\% vs. $36 \%)$. Risk of 28 -day mortality was reduced in the group who received IVC (HR $=0.14,95 \%$ CI, $0.03-0.72, p=0.037)$. Six $(8 \%)$ patients with severe or critical disease died at the end of 28 days; one (17\%) received IVC, and five ( $83 \%)$ standard therapy. The risks of mortality were even higher for patients who did not receive IVC if they had severe or critical disease $(\mathrm{HR}=9.9,95 \% \mathrm{CI}, 1.8-54)$ or were aged $>60$ years $(\mathrm{HR}=8.0,95 \%$ CI, 1.2-51). Furthermore, C-reactive protein (CRP), procalcitonin (PCT) and interleukin-8 (IL-8) concentrations were reduced in the patients with COVID-19 who received IVC. Other retrospective cohort studies from Wuhan, China, also reported reductions in inflammatory markers (CRP, IL-6, TNF- $\alpha$ ) and ameliorated cardiac injury in patients with severe COVID19 who had received a loading dose of $100 \mathrm{mg} / \mathrm{kg}$ bodyweight 6 hourly on the first day followed by $100 \mathrm{mg} / \mathrm{kg} 12$ hourly for the following 5 days, relative to those who received standard therapy only $[33,34]$. 
Table 3. Retrospective cohort studies investigating the effect of intravenous vitamin C (IVC) in patients with COVID-19.

\section{Population \\ Mean Age \\ Location}

76 patients with moderate to severe COVID-19

Age $=61(52-71)$ years

Xi'an, Shaanxi, China

\section{Intervention \\ Duration}

Findings (IVC vs. Control)

Reference
$\mathrm{IVC}^{1} 6 \mathrm{~g} / 12 \mathrm{~h}$ on first day, $6 \mathrm{~g} /$ day for following 4 days

+ standard therapy $(\mathrm{n}=30)$

or standard therapy $(n=46)$ for 5 days
Improved oxygen support status (64\% vs. $36 \%)$

Reduced risk of 28-day mortality

$\left(\mathrm{HR}^{2}=0.14,95 \%\right.$ CI, 0.03-0.72, $\left.p=0.037\right)$

Reduced CRP ${ }^{3}, \mathrm{PCT}^{4}$ and IL- $8^{5}$ concentrations
Fewer patients progressing to severe type
110 patients with moderate COVID-19 pneumonia Age $=36$ (31-47) years Shanghai, China
IVC $100 \mathrm{mg} / \mathrm{kg} /$ day + standard therapy or standard therapy

(55 per group) for 7 days
Lower activated partial
(4 vs. $12 ; \mathrm{RR}^{6} 0.28$ [0.08, 0.93], $p=0.03$ )

Reduction in duration $(p<0.001)$ and

incidence of $\operatorname{SIRS}^{7}(p=0.008)$

Lower CRP concentrations $(p=0.005)$

thromboplastintime $(p=0.02)$

Higher $\mathrm{CD}_{4}{ }^{+}$(helper) T cells $(p=0.0004)$

Shorter length of hospital stay ( 7 vs. $8 \mathrm{~d}, p=0.05$ )

No difference in re-admission rate $(p=0.94)$, admission to $\mathrm{ICU}^{8}$, need for advanced oxygen support $(p=0.49)$, and mortality $(p=0.52)$

Need for advanced medical treatment $(p<0.001)$
34 critically ill patients with COVID-19

Age $=65 \pm 12$ years New York, USA

$$
\begin{gathered}
\text { IVC } 2 \mathrm{~g} / \text { day }+ \text { standard } \\
\text { therapy }(\mathrm{n}=153) \\
\text { or standard therapy } \\
\quad(\mathrm{n}=170)
\end{gathered}
$$

Higher rate of hospital mortality (19

[79\%] vs. $7[88 \%], p=0.049)$ and SOFA

scores $(12 \pm 3$ vs. $8 \pm 4, p<0.005)$

No difference in daily vasopressor requirement or ICU length of stay

$$
\begin{aligned}
& + \text { standard therapy }(n=8) \\
& \text { or standard therapy }(n=24) \\
& \text { for } 4 \text { days }
\end{aligned}
$$$$
\text { IVC } 1.5 \mathrm{~g} / 6 \mathrm{~h}
$$

236 patients with severe COVID-19

Age $=66$ (57-73) years Wuhan, China

113 patients with severe COVID-19 and cardiac injury Age = 68 (59-77) years Wuhan, China
IVC $100 \mathrm{mg} / \mathrm{kg} / 6 \mathrm{~h}$ on day 1 then $100 \mathrm{mg} / \mathrm{kg} / 12 \mathrm{~h}$ for the next 5 days + standard therapy $(n=85)$ or standard therapy $(n=151)$

IVC $100 \mathrm{mg} / \mathrm{kg} / 6 \mathrm{~h}$ on day 1 then $100 \mathrm{mg} / \mathrm{kg} / 12 \mathrm{~h}$ for the next 5 days + standard therapy $(n=51)$

or standard therapy $(n=62)$
Reduction in inflammatory markers (CRP, $p=0.032$; IL-6, $p=0.005$; TNF- $\alpha^{9}$,

$$
p=0.015)
$$

IVC was associated with ameliorated cardiac injury (OR 2.42 [1.02, 5.73],

$$
p=0.04)
$$

Reduced levels of inflammatory markers

(CRP, IL-6, IL-8, TNF- $\alpha$ ) at 21 days of hospitalisation

\footnotetext{
${ }^{1}$ IVC: intravenous vitamin $\mathrm{C}^{2}{ }^{2} \mathrm{HR}$ : hazard ratio, ${ }^{3} \mathrm{CRP}$ : C-reactive protein, ${ }^{4}$ PCT: procalcitonin, ${ }^{5} \mathrm{IL}$ : interleukin, ${ }^{6}$ RR: relative risk, ${ }^{7}$ SIRS: systemic inflammatory response syndrome, ${ }^{8}$ ICU: Intensive care unit, ${ }^{9}$ TNF: tumor necrosis factor.
}

Severe COVID-19 is mainly characterized by deteriorating respiratory function and rapid progression of radiological lesions, while the critical type requires mechanical ventilation and is accompanied by shock or multiple organ failure. These two types are reported to be associated with a mortality rate as high as 66\% [35]. To investigate the effect of high-dose IVC in the prevention of disease aggravation from moderate to severe, a study in Shanghai, China matched 110 patients with moderate COVID-19 pneumonia (55 per group) who received either IVC $100 \mathrm{mg} / \mathrm{kg}$ (7.5 g for $75 \mathrm{~kg}$ person) or standard care [35]. A third fewer 
patients progressed to severe status when given IVC (4 vs. 12; RR $0.28[0.08,0.93], p=0.03$ ). The duration $(p<0.001)$ and incidence $(2 / 21$ vs. $10 / 22, p=0.08)$ of systemic inflammatory response syndrome (SIRS) and CRP levels $(p=0.05)$ were also reduced. Blood clotting time was improved (activated partial thromboplastin time, $p=0.02$ ), and $\mathrm{CD}_{4}{ }^{+}$(helper) $\mathrm{T}$ cell numbers were increased $(p=0.04)$.

Two retrospective cohort studies have reported no positive effects of IVC administration (Table 3). A retrospective study with propensity score matching in a New York ICU initiated IVC 1.5 g every six hours within $7 \pm 5$ days from admission $(n=8)$ for up to four days and compared the outcomes with untreated patients $(n=24)$ [37]. Patients in the IVC group had higher rates of hospital mortality $(19$ [79\%] vs. 7 [88\%], $p=0.049)$ and mean SOFA scores post-treatment $(12 \pm 3$ vs. $8 \pm 4, p<0.005)$. There was no difference in the daily vasopressor requirement or in ICU length of stay between the treatment and comparator groups. However, it should be noted that the intervention group comprised only 8 patients and their mean SOFA score was nearly 3 points higher than the control group indicating greater severity of the treatment group at baseline. Furthermore, higher numbers of patients in the control group received convalescent plasma and prednisolone, which is highly suggestive that the standard of care may have been different between the patients included in this retrospective analysis. Another study in Ankara, Turkey administered IVC at $2 \mathrm{~g} /$ day initiated within a median duration of three days after admission $(n=153)$ compared with a group who received standard care alone $(n=170)$ [36]. There was a trend towards a decrease in duration of hospital stay ( 7 vs. 8 days, $p=0.05$ ), no differences in re-admission rate $(p=0.94)$, admission to intensive care, need for advanced oxygen support $(p=0.49)$ or mortality $(p=0.52)$, but a higher need for advanced medical treatment $(p<0.001)$. However, as discussed below, emerging evidence is indicating that the vitamin $C$ dosing regimens used in many of these studies may be inadequate in the critical stages of COVID-19.

\section{Randomised Controlled Trials with Oral Vitamin C Supplementation}

Fewer trials have investigated the effect of oral vitamin C in patients with COVID-19. A trial of 214 outpatients in the USA administered standard care, or vitamin C (8 g/day), or zinc (50 mg/day), or a combination of both vitamin C and zinc, and showed an $18 \%$ (1.2 day) reduction in the number of days to reach $50 \%$ reduction in symptoms in the participants who received the vitamin C (Table 4) [38]. Unfortunately, this trial was halted early resulting in a non-significant difference compared with the control group $(p=0.38)$. Nevertheless, independent statistical analysis of the results showed a $71 \%(p=0.036)$ increase in the rate of recovery in the vitamin C group compared to standard care [39]. Thus, a better outcome might have been achieved if the trial had continued to the full sample size. 
Table 4. Studies investigating the effect of oral vitamin C in patients with COVID-19.

\begin{tabular}{|c|c|c|c|}
\hline $\begin{array}{l}\text { Population } \\
\text { Mean Age } \\
\text { Location }\end{array}$ & $\begin{array}{l}\text { Intervention } \\
\text { Duration }\end{array}$ & Findings (Vitamin C vs. Control) & Reference \\
\hline \multicolumn{4}{|c|}{ Randomised Controlled Trials } \\
\hline $\begin{array}{c}214 \text { patients with SARS-CoV-2 } \\
\text { Age }=45 \pm 15 \text { years } \\
\text { Ohio and Florida, USA }\end{array}$ & $\begin{array}{c}8 \mathrm{~g} / \text { day oral vitamin } \mathrm{C} \\
\text { or } 50 \mathrm{mg} / \text { day zinc gluconate } \\
\text { or vitamin } \mathrm{C}+\text { zinc gluconate } \\
\text { or standard care } \\
\quad(\mathrm{n}=48-58 \text { per group }) \\
\text { for } 10 \text { days }\end{array}$ & $\begin{array}{l}18 \% \text { (1.2 day) decrease in time to } 50 \% \\
\text { reduction of symptoms }(p=0.38) \\
\text { Vitamin C increased the rate of } \\
\text { recovery by } 71 \%(p=0.036)\end{array}$ & [39] \\
\hline $\begin{array}{c}72 \text { non-serious hospitalised } \\
\text { patients } \\
\text { Mean age }=36 \text { years } \\
\text { Isfahan, Iran }\end{array}$ & $\begin{array}{c}1000 \mathrm{mg} / \text { day oral vitamin C (plus } \\
400 \text { IU / day vitamin E) } \\
\text { or standard care } \\
(\mathrm{n}=34-38 \text { per group) } \\
\text { until hospital discharge or ICU } \\
\text { admission }\end{array}$ & $\begin{array}{c}\text { No differences in clinical improvement } \\
\text { or duration of hospitalisation }(p=0.82) \\
\text { No patients died in the study }\end{array}$ & [40] \\
\hline \multicolumn{4}{|c|}{ Retrospective cohort study } \\
\hline $\begin{array}{l}296 \text { critically ill patients } \\
\text { Age }=61 \pm 15 \\
\text { Riyadh, Saudi Arabia }\end{array}$ & $\begin{array}{c}1000 \mathrm{mg} / \text { day oral vitamin } \mathrm{C} \\
\text { or standard care } \\
(\mathrm{n}=148 \text { per group) } \\
\text { for approx. } 11 \text { days }\end{array}$ & $\begin{array}{l}\text { No association with hospital or 30-day } \\
\text { mortality, or organ injury } \\
\text { Longer ICU and hospital length of stay } \\
\text { Decreased incidence of thrombosis } \\
\text { (6 vs. } 13 \% \text {, OR } 0.42[0.18-0.94], p=0.03 \text { ) }\end{array}$ & [41] \\
\hline
\end{tabular}

In another oral intervention study, hospitalised patients with non-severe COVID-19 in Isfahan, Iran, received low-dose oral vitamin C (1000 mg/day) plus oral vitamin E (400 IU/day) in addition to the national standard treatment regimen (hydroxychloroquine) or standard regimen alone [40]. There were no significant differences in the duration of hospitalisation $(p=0.82)$. A recent retrospective cohort study of patients who received low-dose oral vitamin C (1000 mg/day) indicated no association with hospital or 30-day mortality or organ injury, a longer ICU and hospital length of stay, but they did observe a significantly decreased incidence of thrombosis [41]. Overall, low-dose oral intervention appears to be less effective than high-dose oral and intravenous vitamin $C$.

\section{Case-Control Study of Oral Vitamin C Supplementation}

A hospital-based matched case-control study was conducted among health-care workers in India, from September to October 2020 [42]. Cases and controls were health-care workers who tested positive and negative, respectively, for SARS-CoV-2 infection. Out of 67 participants, 54 participants took a dose of $500 \mathrm{mg}$ vitamin $C$ once daily, and 13 participants took $500 \mathrm{mg}$ twice daily. These participants were then matched with 305 participants who did not take any vitamin $C$. Vitamin $C$ prophylaxis had no significant association with SARS-CoV-2 infection (OR 0.71, 95\% CI, 0.40-1.26). The outcomes from this study correlate with previous research indicating that prophylactic vitamin $C$ did not decrease the risk of the common cold in the general population, except in specific subgroups who experienced enhanced physical stress [43]. However, prophylactic vitamin C has been shown to decrease the risk of more severe respiratory conditions such as pneumonia [44]. As such, regular vitamin $C$ supplementation may prevent mild SARS-CoV-2 infection from progressing to the more severe conditions of pneumonia and sepsis that are observed in critical COVID-19, thus potentially decreasing the need for hospitalisation and intensive care.

\section{Safety of Oral and Intravenous Vitamin C}

Uptake of oral vitamin $C$ is regulated by the kinetics of the intestinal vitamin $C$ transporter (SVCT-1), which limits the amount of vitamin C that can be absorbed at any one time to between 200 and $500 \mathrm{mg}$ [11,45]. Thus, adverse events related to high-dose oral 
vitamin $C$ are generally related to gastrointestinal disturbance from unabsorbed vitamin $C$ passing through the intestines [46]. In contrast, intravenous vitamin $C$ by-passes the regulated intestinal uptake of oral vitamin $C$, resulting in significantly higher circulating concentrations [16]. This elevated peak is still relatively transient, however, because vitamin $\mathrm{C}$ is water-soluble and is rapidly cleared by the kidneys, with a half-life of approx. $2-4 \mathrm{~h}$ depending on the administration regimen $[47,48]$. Nevertheless, circulating vitamin $C$ concentrations can remain elevated if IVC is administered to people with renal dysfunction due to their attenuated ability to clear the infused doses.

Oxidative degradation of vitamin $C$ can result in elevated oxalate concentrations which can potentially result in oxalate nephropathy, particularly in people predisposed to the condition $[49,50]$. However, because oxidised vitamin C (dehydroascorbic acid) is readily reduced back to vitamin $C$ by both chemical and enzymatic means in the body, further degradation of dehydroascorbic acid to oxalate would only occur in the absence of other reducing agents. Furthermore, in the ICU setting, patients with renal insufficiency generally receive intermittent or continuous haemodialysis, which decreases circulating vitamin C concentrations [51]. People with glucose-6-phosphatedehydrogenase deficiency can experience haemolytic anaemia with high-dose IVC administration due to an inability to neutralise excess hydrogen peroxide, however, this is less likely to occur at the lower divided doses administered in ICU settings [52]. Spurious point-of-care glucometer readings can occur following IVC administration due to interference of high concentrations of vitamin $C$ with specific glucometer biochemistry [53]. At the doses used in the ICU setting, this generally only occurs in patients with renal impairment [54].

To date, no adverse events have been reported in the published vitamin C and COVID19 clinical trials (Tables 2-4). There have been two cases reported in the literature of oxalate nephropathy in patients with COVID-19 who were administered IVC at a dose of $50 \mathrm{mg} / \mathrm{kg} 4 \times$ daily, although the cause of the acute kidney injury was acknowledged as likely multifactorial [55]. A third case occurred in a kidney transplant recipient with COVID-19 who had apparently consumed oral vitamin C (500 mg $3 \times$ daily), however, the connection to vitamin $\mathrm{C}$ was extremely tenuous due to no evidence of elevated oxalate concentrations in their blood or urine [56]. Thus, there is no evidence that vitamin C is harmful when the above contraindications are taken into consideration [49].

\section{Future Directions}

There are currently numerous trials up and running around the world investigating vitamin $C$ for the prevention and treatment of COVID-19. A number of these trials comprise combination therapies with other nutrients and/or medications, such as dexamethasone, however it will be difficult to tease out the contribution of vitamin $C$ to any observed effects in these trials. Although pharmacokinetic studies have indicated that doses of vitamin $C$ of 2-3 g/day can saturate the blood of critically ill patients [14,15], it is likely that higher doses will be required to optimise tissue levels due to possible downregulation of cellular vitamin $\mathrm{C}$ transporters as a result of elevated inflammation [57]. This premise is supported by trials which have shown dose-dependent effects of vitamin C administration [58]. Thus, future trials should explore optimisation of dosing regimens. Early administration of vitamin $C$ is also likely to have greater benefit [59,60].

Two large monotherapy RCTs are currently underway internationally (LOVIT-COVID NCT04401150 and REMAP-CAP NCT02735707) with IVC dose and duration of $200 \mathrm{mg} / \mathrm{kg} / \mathrm{day}$ for 4 days. Of note, these trials will be assessing survivor health-related quality of life at 6 months. This is relevant to the long-term complications of COVID-19, or what is being referred to as 'long COVID' [61,62]. However, as has been alluded to above, cessation of IVC after only a few days may result in return to hypovitaminosis $C$ status in some patients, and is thus unlikely to have an impact on long term quality of life outcomes. Therefore, moving forward, trials may want to adopt a more pragmatic design whereby patients receive IVC whilst hospitalised and then move to oral vitamin $C$ following discharge to determine if this has a greater impact on the ongoing complications of long COVID. 


\section{Conclusions}

Observational studies have indicated that patients with COVID-19 have high rates of hypovitaminosis $C$ and vitamin $C$ deficiency, which are comparable to patients with sepsis and septic shock [7]. Previous studies of high-dose IVC administration in patients with sepsis and ARDS have shown reduced duration of ICU and hospital stay as well as decreased mortality $[27,63]$. Based on the evidence from preliminary RCTs and retrospective cohort studies, vitamin C appears to also support positive outcomes in COVID-19 in both inpatient and outpatient settings, leading to a beneficial effect in patients with moderate symptoms, as well as patients with pneumonia, sepsis and ARDS. Intervention with IVC resulted in improved oxygenation and pulmonary function, reduced inflammatory markers and temperature, decreased days in ICU and hospital, and decreased mortality, particularly in the more severely ill patients. Oral supplementation in mild to moderate cases also increased the rate of recovery when taken in high-doses.

Overall, the intervention studies to date have a number of limitations such as small sample sizes and early termination of some studies, differences in vitamin $C$ dose and duration and lack of optimisation of these, lack of placebo controls, and no pre-and postintervention plasma vitamin $C$ concentrations. However, living meta-analysis of the studies as they are published is supporting the premise that high-dose IVC can improve the complications associated with COVID-19 and potentially decrease mortality [64]. Notably, there have been no adverse events reported in the published trials to date.

Author Contributions: Conceptualisation, P.H., A.C.C.; writing—original draft preparation, P.H., A.C.C., M.Z.; writing-review and editing, M.P.V. All authors have read and agreed to the published version of the manuscript.

Funding: Partial funding was provided by the VitaminC4COVID not-for-profit initiative.

Institutional Review Board Statement: Not applicable.

Informed Consent Statement: Not applicable.

Data Availability Statement: Not applicable.

Acknowledgments: Thank you to David Smith for critically reviewing the manuscript.

Conflicts of Interest: P.H. is founder of the VitaminC4COVID initiative; A.C. is the chair and M.P.V. is a member of the independent Scientific Advisory Board.

\section{References}

1. Rabi, F.A.; Al Zoubi, M.S.; Kasasbeh, G.A.; Salameh, D.M.; Al-Nasser, A.D. SARS-CoV-2 and Coronavirus Disease 2019: What We Know So Far. Pathogens 2020, 9, 231. [CrossRef] [PubMed]

2. Cui, J.; Li, F.; Shi, Z.L. Origin and evolution of pathogenic coronaviruses. Nat. Rev. Microbiol. 2019, 17, 181-192. [CrossRef] [PubMed]

3. Zhu, N.; Zhang, D.; Wang, W.; Li, X.; Yang, B.; Song, J.; Zhao, X.; Huang, B.; Shi, W.; Lu, R.; et al. A Novel Coronavirus from Patients with Pneumonia in China, 2019. N. Engl. J. Med. 2020, 382, 727-733. [CrossRef] [PubMed]

4. Gorbalenya, A.E.; Baker, S.C.; Baric, R.S.; de Groot, R.J.; Drosten, C.; Gulyaeva, A.A.; Haagmans, B.L.; Lauber, C.; Leontovich, A.M.; Neuman, B.W.; et al. The species Severe acute respiratory syndrome-related coronavirus: Classifying 2019-nCoV and naming it SARS-CoV-2. Nat. Microbiol. 2020, 5, 536-544. [CrossRef]

5. WHO Coronavirus Disease 2019 (COVID-19) Situation Report as of 2 August 2021 (5:19pm CEST). Available online: https: // covid19.who.int/ (accessed on 3 August 2021).

6. Centres for Disease Control and Prevention Assessing Risk Factors for Severe COVID-19 Illness 2020. Available online: https:/ / www.cdc.gov/coronavirus/2019-ncov/covid-data/investigations-discovery/assessing-risk-factors.html (accessed on 18 August 2021).

7. Carr, A.C. Vitamin C in pneumonia and sepsis. In Vitamin C: New Biochemical and Functional Insights; Chen, Q.V.M., Ed.; CRC Press/Taylor \& Francis: Boca Raton, FL, USA, 2020; pp. 115-135.

8. Holford, P.; Carr, A.C.; Jovic, T.H.; Ali, S.R.; Whitaker, I.S.; Marik, P.E.; Smith, A.D. Vitamin C-An Adjunctive Therapy for Respiratory Infection, Sepsis and COVID-19. Nutrients 2020, 12, 3760. [CrossRef] [PubMed]

9. Carr, A.C.; Rowe, S. Factors Affecting Vitamin C Status and Prevalence of Deficiency: A Global Health Perspective. Nutrients 2020, 12, 1963. [CrossRef] [PubMed]

10. Hemilä, H. Vitamin C and Infections. Nutrients 2017, 9, 339. [CrossRef] 
11. Levine, M.; Conry-Cantilena, C.; Wang, Y.; Welch, R.W.; Washko, P.W.; Dhariwal, K.R.; Park, J.B.; Lazarev, A.; Graumlich, J.F.; King, J.; et al. Vitamin C pharmacokinetics in healthy volunteers: Evidence for a recommended dietary allowance. Proc. Natl. Acad. Sci. USA 1996, 93, 3704-3709. [CrossRef] [PubMed]

12. Levine, M.; Wang, Y.; Padayatty, S.J.; Morrow, J. A new recommended dietary allowance of vitamin C for healthy young women. Proc. Natl. Acad. Sci. USA 2001, 98, 9842-9846. [CrossRef] [PubMed]

13. Carr, A.C.; Rosengrave, P.C.; Bayer, S.; Chambers, S.; Mehrtens, J.; Shaw, G.M. Hypovitaminosis C and vitamin C deficiency in critically ill patients despite recommended enteral and parenteral intakes. Critical Care 2017, 21, 300. [CrossRef]

14. Long, C.L.; Maull, K.I.; Krishnan, R.S.; Laws, H.L.; Geiger, J.W.; Borghesi, L.; Franks, W.; Lawson, T.C.; Sauberlich, H.E. Ascorbic acid dynamics in the seriously ill and injured. J. Surg Res. 2003, 109, 144-148. [CrossRef]

15. De Grooth, H.J.; Manubulu-Choo, W.P.; Zandvliet, A.S.; Spoelstra-de Man, A.M.E.; Girbes, A.R.; Swart, E.L.; Oudemans-van Straaten, H.M. Vitamin C Pharmacokinetics in Critically Ill Patients: A Randomized Trial of Four IV Regimens. Chest 2018, 153, 1368-1377. [CrossRef]

16. Padayatty, S.J.; Sun, H.; Wang, Y.; Riordan, H.D.; Hewitt, S.M.; Katz, A.; Wesley, R.A.; Levine, M. Vitamin C pharmacokinetics: Implications for oral and intravenous use. Ann. Intern. Med. 2004, 140, 533-537. [CrossRef] [PubMed]

17. World Health Organization. A Coordinated Global Research Roadmap: 2019 Novel Coronavirus; World Health Organization: Geneva, Switzerland, 2020.

18. Carr, A.C.; Spencer, E.; Dixon, L.; Chambers, S.T. Patients with Community Acquired Pneumonia Exhibit Depleted Vitamin C Status and Elevated Oxidative Stress. Nutrients 2020, 12, 1318. [CrossRef]

19. Chakrabarti, B.; Banerjee, S. Dehydroascorbic acid level in blood of patients suffering from various infectious diseases. Proc. Soc. Exp. Biol. Med. 1955, 88, 581-583. [CrossRef]

20. Bakaev, V.V.; Duntau, A.P. Ascorbic acid in blood serum of patients with pulmonary tuberculosis and pneumonia. Int. J. Tuberc. Lung. Dis. 2004, 8, 263-266. [PubMed]

21. Xing, Y.; Zhao, B.; Yin, L.; Guo, M.; Shi, H.; Zhu, Z.; Zhang, L.; He, J.; Ling, Y.; Gao, M.; et al. Vitamin C supplementation is necessary for patients with coronavirus disease: An ultra-high-performance liquid chromatography-tandem mass spectrometry finding. J. Pharm. Biomed. Anal. 2021, 196, 113927. [CrossRef] [PubMed]

22. Arvinte, C.; Singh, M.; Marik, P.E. Serum Levels of Vitamin C and Vitamin D in a Cohort of Critically Ill COVID-19 Patients of a North American Community Hospital Intensive Care Unit in May 2020: A Pilot Study. Med. Drug Discov. 2020, 8, 100064. [CrossRef]

23. Chiscano-Camón, L.; Ruiz-Rodriguez, J.C.; Ruiz-Sanmartin, A.; Roca, O.; Ferrer, R. Vitamin C levels in patients with SARS-CoV-2associated acute respiratory distress syndrome. Crit. Care 2020, 24, 522. [CrossRef] [PubMed]

24. Tomasa-Irriguible, T.M.; Bielsa-Berrocal, L. COVID-19: Up to $82 \%$ critically ill patients had low Vitamin C values. Nutr. J. 2021, 20, 66. [CrossRef]

25. Muhammad, Y.; Kani, Y.A.; Iliya, S.; Muhammad, J.B.; Binji, A.; El-Fulaty Ahmad, A.; Kabir, M.B.; Umar Bindawa, K.; Ahmed, A. Deficiency of antioxidants and increased oxidative stress in COVID-19 patients: A cross-sectional comparative study in Jigawa, Northwestern Nigeria. SAGE Open. Med. 2021, 9, 2050312121991246. [CrossRef]

26. Pincemail, J.; Cavalier, E.; Charlier, C.; Cheramy-Bien, J.P.; Brevers, E.; Courtois, A.; Fadeur, M.; Meziane, S.; Goff, C.L.; Misset, B.; et al. Oxidative Stress Status in COVID-19 Patients Hospitalized in Intensive Care Unit for Severe Pneumonia. A Pilot Study. Antioxidants 2021, 10, 257. [CrossRef] [PubMed]

27. Fowler, A.A.; Truwit, J.D.; Hite, R.D.; Morris, P.E.; DeWilde, C.; Priday, A.; Fisher, B.; Thacker, L.R.; Natarajan, R.; Brophy, D.F.; et al. Effect of Vitamin C Infusion on Organ Failure and Biomarkers of Inflammation and Vascular Injury in Patients With Sepsis and Severe Acute Respiratory Failure: The CITRIS-ALI Randomized Clinical Trial. JAMA 2019, 322, 1261-1270. [CrossRef] [PubMed]

28. Zhang, J.; Rao, X.; Li, Y.; Zhu, Y.; Liu, F.; Guo, G.; Luo, G.; Meng, Z.; De Backer, D.; Xiang, H.; et al. Pilot trial of high-dose vitamin C in critically ill COVID-19 patients. Ann. Int. Care 2021, 11, 5. [CrossRef] [PubMed]

29. Borrelli, E.; Roux-Lombard, P.; Grau, G.E.; Girardin, E.; Ricou, B.; Dayer, J.; Suter, P.M. Plasma concentrations of cytokines, their soluble receptors, and antioxidant vitamins can predict the development of multiple organ failure in patients at risk. Crit. Care Med. 1996, 24, 392-397. [CrossRef] [PubMed]

30. Kumari, P.; Dembra, S.; Dembra, P.; Bhawna, F.; Gul, A.; Ali, B.; Sohail, H.; Kumar, B.; Memon, M.K.; Rizwan, A. The Role of Vitamin C as Adjuvant Therapy in COVID-19. Cureus 2020, 12, e11779. [CrossRef]

31. Jamali Moghadam Siahkali, S.; Zarezade, B.; Koolaji, S.; Seyed Alinaghi, S.; Zendehdel, A.; Tabarestani, M.; Sekhavati Moghadam, E.; Abbasian, L.; Dehghan Manshadi, S.A.; Salehi, M. Safety and effectiveness of high-dose vitamin C in patients with COVID-19: A randomized open-label clinical trial. Eur. J. Med. Res. 2021, 26, 20. [CrossRef]

32. Gao, D.; Xu, M.; Wang, G.; Lv, J.; Ma, X.; Guo, Y.; Zhang, D.; Yang, H.; Jiang, W.; Deng, F.; et al. The efficiency and safety of high-dose vitamin C in patients with COVID-19: A retrospective cohort study. Aging Al. N.Y. 2021, 13, 7020-7034. [CrossRef] [PubMed]

33. Xia, G.; Fan, D.; He, Y.; Zhu, Y.; Zheng, Q. High-dose intravenous vitamin C attenuates hyperinflammation in severe coronavirus disease 2019. Nutrition 2021, 91-92, 111405. [CrossRef]

34. Xia, G.; Qin, B.; Ma, C.; Zhu, Y.; Zheng, Q. High-dose vitamin C ameliorates cardiac injury in COVID-19 pandemic: A retrospective cohort study. Aging Al. N.Y. 2021, 13, 20906-20914. [CrossRef] [PubMed] 
35. Zhao, B.; Liu, M.; Liu, P.; Peng, Y.; Huang, J.; Li, M.; Wang, Y.; Xu, L.; Sun, S.; Qi, X.; et al. High Dose Intravenous Vitamin C for Preventing The Disease Aggravation of Moderate COVID-19 Pneumonia. A Retrospective Propensity Matched Before-After Study. Front. Pharmacol. 2021, 12, 519. [CrossRef]

36. Suna, K.; Melahat, U.; Murat, Y.; Figen Ö, E.; Ayperi, Ö. Effect of high-dose intravenous vitamin C on prognosis in patients with SARS-CoV-2 pneumonia. Med. Clin. Barc. 2021. [CrossRef]

37. Li, M.; Ching, T.H.; Hipple, C.; Lopez, R.; Sahibzada, A.; Rahman, H. Use of Intravenous Vitamin C in Critically Ill Patients With COVID-19 Infection. J. Pharm. Pract. 2021. [CrossRef] [PubMed]

38. Thomas, S.; Patel, D.; Bittel, B.; Wolski, K.; Wang, Q.; Kumar, A.; Il'Giovine, Z.J.; Mehra, R.; McWilliams, C.; Nissen, S.E.; et al. Effect of High-Dose Zinc and Ascorbic Acid Supplementation vs Usual Care on Symptom Length and Reduction Among Ambulatory Patients With SARS-CoV-2 Infection: The COVID A to Z Randomized Clinical Trial. JAMA Netw. Open. 2021, 4, e210369. [CrossRef] [PubMed]

39. Hemilä, H.; Carr, A.; Chalker, E. Vitamin C May Increase the Recovery Rate of Outpatient Cases of SARS-CoV-2 Infection by $70 \%$ : Reanalysis of the COVID A to Z Randomized Clinical Trial. Front. Immunol. 2021, 12, 1628. [CrossRef] [PubMed]

40. Hakamifard, A.; Soltani, R.; Maghsoudi, A.; Rismanbaf, A.; Aalinezhad, M.; Tarrahi, M.; Mashayekhbakhsh, S.; Dolatshahi, K. The effect of vitamin $\mathrm{E}$ and vitamin $\mathrm{C}$ in patients with COVID-19 pneumonia; a randomized controlled clinical trial. Immunopathol. Persa 2021, 7. [CrossRef]

41. Al Sulaiman, K.; Aljuhani, O.; Saleh, K.B.; Badreldin, H.A.; Al Harthi, A.; Alenazi, M.; Alharbi, A.; Algarni, R.; Al Harbi, S.; Alhammad, A.M.; et al. Ascorbic acid as an adjunctive therapy in critically ill patients with COVID-19: A propensity score matched study. Sci. Rep. 2021, 11, 17648. [CrossRef]

42. Behera, P.; Patro, B.K.; Singh, A.K.; Chandanshive, P.D.; Ravikumar, S.R.; Pradhan, S.K.; Pentapati, S.S.K.; Batmanabane, G.; Mohapatra, P.R.; Padhy, B.M.; et al. Role of ivermectin in the prevention of SARS-CoV-2 infection among healthcare workers in India: A matched case-control study. PLoS ONE 2021, 16, e0247163. [CrossRef] [PubMed]

43. Douglas, R.M.; Hemilä, H.; Chalker, E.; Treacy, B. Vitamin C for preventing and treating the common cold. Cochran. Database Syst. Rev. 2007. [CrossRef]

44. Hemilä, H.; Louhiala, P. Vitamin C for preventing and treating pneumonia. Cochrane Database Syst. Rev. 2013. [CrossRef] [PubMed]

45. Savini, I.; Rossi, A.; Pierro, C.; Avigliano, L.; Catani, M.V. SVCT1 and SVCT2: Key proteins for vitamin C uptake. Amino Acids 2008, 34, 347-355. [CrossRef] [PubMed]

46. Institute of Medicine (US) Panel on Dietary Antioxidants and Related Compounds. In Dietary Reference Intakes for Vitamin C, Vitamin E, Selenium, and Carotenoids; National Academies Press (US): Washington, DC, USA, 2000. [CrossRef]

47. Carr, A.C.; Cook, J. Intravenous Vitamin C for Cancer Therapy-Identifying the Current Gaps in Our Knowledge. Front. Physiol. 2018, 9, 1182. [CrossRef] [PubMed]

48. Hudson, E.P.; Collie, J.T.; Fujii, T.; Luethi, N.; Udy, A.A.; Doherty, S.; Eastwood, G.; Yanase, F.; Naorungroj, T.; Bitker, L.; et al. Pharmacokinetic data support 6-hourly dosing of intravenous vitamin $\mathrm{C}$ to critically ill patients with septic shock. Crit. Care Resusc. 2019, 21, 236-242. [PubMed]

49. Yanase, F.; Fujii, T.; Naorungroj, T.; Belletti, A.; Luethi, N.; Carr, A.C.; Young, P.J.; Bellomo, R. Harm of IV High-Dose Vitamin C Therapy in Adult Patients: A Scoping Review. Crit. Care Med. 2020, 48, e620-e628. [CrossRef] [PubMed]

50. Padayatty, S.J.; Sun, A.Y.; Chen, Q.; Espey, M.G.; Drisko, J.; Levine, M. Vitamin C: Intravenous use by complementary and alternative medicine practitioners and adverse effects. PLoS ONE 2010, 5, e11414. [CrossRef] [PubMed]

51. Honore, P.M.; Spapen, H.D.; Marik, P.; Boer, W.; Oudemans-van Straaten, H. Dosing vitamin C in critically ill patients with special attention to renal replacement therapy: A narrative review. Ann. Int. Care 2020, 10, 23. [CrossRef] [PubMed]

52. Marik, P.E. Is intravenous vitamin C contraindicated in patients with G6PD deficiency? Crit. Care 2019, 23, 109. [CrossRef]

53. Tang, Z.; Du, X.; Louie, R.F.; Kost, G.J. Effects of drugs on glucose measurements with handheld glucose meters and a portable glucose analyzer. Am. J. Clin. Pathol. 2000, 113, 75-86. [CrossRef] [PubMed]

54. Stephenson, E.; Hooper, M.; Marik, P. Vitamin C And Point Of Care Glucose Measurements: A Retrospective, Observational Study. Chest 2018, 154, 255A. [CrossRef]

55. Fontana, F.; Cazzato, S.; Giovanella, S.; Ballestri, M.; Leonelli, M.; Mori, G.; Alfano, G.; Ligabue, G.; Magistroni, R.; Cenacchi, G.; et al. Oxalate Nephropathy Caused by Excessive Vitamin C Administration in 2 Patients With COVID-19. Kidney Int. Rep. 2020, 5 , 1815-1822. [CrossRef] [PubMed]

56. Anandh, U.; Gowrishankar, S.; Sharma, A.; Salama, A.; Dasgupta, I. Kidney transplant dysfunction in a patient with COVID - 19 infection: Role of concurrent Sars-Cov 2 nephropathy, chronic rejection and vitamin C-mediated hyperoxalosis: Case report. BMC Nephrol. 2021, 22, 91. [CrossRef] [PubMed]

57. Carr, A.C. Is "Mega-Dose" IV Vitamin C Required for Septic and Critical Coronavirus Disease 2019 Patients? Crit. Care Med. 2021, 49, e477-e478. [CrossRef] [PubMed]

58. Fowler, A.A.; Syed, A.A.; Knowlson, S.; Sculthorpe, R.; Farthing, D.; DeWilde, C.; Farthing, C.A.; Larus, T.L.; Martin, E.; Brophy, D.F.; et al. Phase I safety trial of intravenous ascorbic acid in patients with severe sepsis. J. Transl. Med. 2014, 12, 32. [CrossRef]

59. Frommelt, M.A.; Kory, P.; Long, M.T. Letter on Update to the Vitamin C, Thiamine, and Steroids in Sepsis (VICTAS) Protocol. Trials 2020, 21, 350. [CrossRef] [PubMed] 
60. Long, M.T.; Frommelt, M.A.; Ries, M.P.; Murray, M.; Osman, F.; Krause, B.M.; Kory, P. Early hydrocortisone, ascorbate and thiamine therapy for severe septic shock. Crit. Care Shock 2020, 23, 23-34.

61. Crook, H.; Raza, S.; Nowell, J.; Young, M.; Edison, P. Long covid-mechanisms, risk factors, and management. Bmj 2021, 374, n1648. [CrossRef] [PubMed]

62. Vollbracht, C.; Kraft, K. Feasibility of Vitamin C in the Treatment of Post Viral Fatigue with Focus on Long COVID, Based on a Systematic Review of IV Vitamin C on Fatigue. Nutrients 2021, 13, 1154. [CrossRef] [PubMed]

63. Hemilä, H.; Chalker, E. Reanalysis of the Effect of Vitamin C on Mortality in the CITRIS-ALI Trial: Important Findings Dismissed in the Trial Report. Front. Med. 2020, 7. [CrossRef] [PubMed]

64. Outcomes in Vitamin C Studies. Available online: https://c19vitaminc.com/cmeta.html (accessed on 26 July 2021). 